\title{
Impact of chicken livestock waste on the quality of sail river in Pekanbaru City, Riau
}

\begin{abstract}
This is research using a survey method, to analyze the impact of waste on the Sail Farm water quality. The sampling location was carried out at five points that are in the chicken farm (T3), 25m (T1) and 10m (T2) leads to the upstream before the drain pipe and 10m (T4) and 25m (T5) downstream after livestock waste disposal pipes. The results showed that the Sail River Water Quality was not met by the standards at T3, all parameters were observed both $\mathrm{pH}$, nitrite, nitrate, ammonium, TDS, TSS, DO, BOD, COD in not meeting government requirements in PP No. 82 of 2001 concerning water quality standards. In other locations (T1, T2, T4, and T5), it is known that the Sail River water quality still meets the applicable regulations.
\end{abstract}

Keywords: water quality, sail river
Volume 5 Issue I - 2020

\section{Kamaruddin Eddiwan \\ Department of Aquatic Resources Management, Faculty of Fisheries and Marine, University of Riau, Indonesia}

Correspondence: Kamaruddin Eddiwan, Department of Aquatic Resources Management, Faculty of Fisheries and Marine, University of Riau, Campus Binawidya JIn HR Soebrantas KM I2, 5, Kec. Taampan, Kota Pekanbaru, Riau, Indonesia, 28293, Email kamaruddineddiwan@gmail.com

Received: March II, 2019 | Published: January 22, 2020

\section{Introduction}

Water is a natural resource for many people, even by all living things. Therefore water resources must be protected so that they can be utilized properly by humans and other living beings. ${ }^{1}$ One of the water sources that are widely used to meet the needs of life and other living things are rivers. Rivers are ecosystems that are very important for humans. The river also provides good water for humans for various activities such as agriculture, industry and domestic. ${ }^{2}$

River water coming out of springs usually has very good quality. But in the process of flowing the water will receive various kinds of pollutants. ${ }^{3}$ Increasing domestic, agricultural and industrial activities will affect and impact the conditions of river water quality, especially domestic activities that provide input of the greatest BOD concentration to river bodies. ${ }^{4}$

Sail River, which is in the city of Pekanbaru, is children of the Siak river. Around the Sail River, there are many chicken farms that are $\pm 10 \mathrm{~m}$ away from the Siak river and sewage disposal pipes directly to the river. The stench of chicken farm waste is very disturbing to the residents around the farm and the river water becomes cloudy and smelly. Waste generated from chicken farming is a form of chicken manure and unpleasant odors and wastewater. Wastewater comes from laundry places for feeding and drinking chicken and other domestic needs. Chicken manure consists of leftovers and undigested cellulose fibers. Chicken manure contains proteins, carbohydrates, fats, and other organic compounds. Proteins in chicken are a source of nitrogen besides other forms of inorganic nitrogen. ${ }^{5}$ The government itself has set a regulation through PP No. 82 of 2001 concerning River Water Quality which regulates pollutant load quality standards that affect river water quality. Based on these matters, it is necessary to analyze the water quality of the Sail River, so that the extent of pollution that occurs in the river is known. This is a village based on physical and chemical properties in accordance with PP No. 82 of 2001 concerning the quality of river water.

\section{Material and method}

\section{Location and time of research}

This research was conducted at the Waste Processing Technology Laboratory, Faculty of Fisheries and Marine Sciences, University of Riau, in May-June 201 8. Sampling locations are carried out on the Sail River City of Pekanbaru at five points. Distance measurement for sampling points is centered on livestock waste disposal pipes. The first point (T1) is $25 \mathrm{~m}$ upstream before the disposal pipe waste; the second point (T2) is $10 \mathrm{~m}$ up to the third point (T3) which is located in the sewage pipe. For the fourth point (T4) spaced the $10 \mathrm{~m}$ downstream after the sewage pipe and the fifth point is $25 \mathrm{~m}$ downstream after the fourth point (Figure 1).

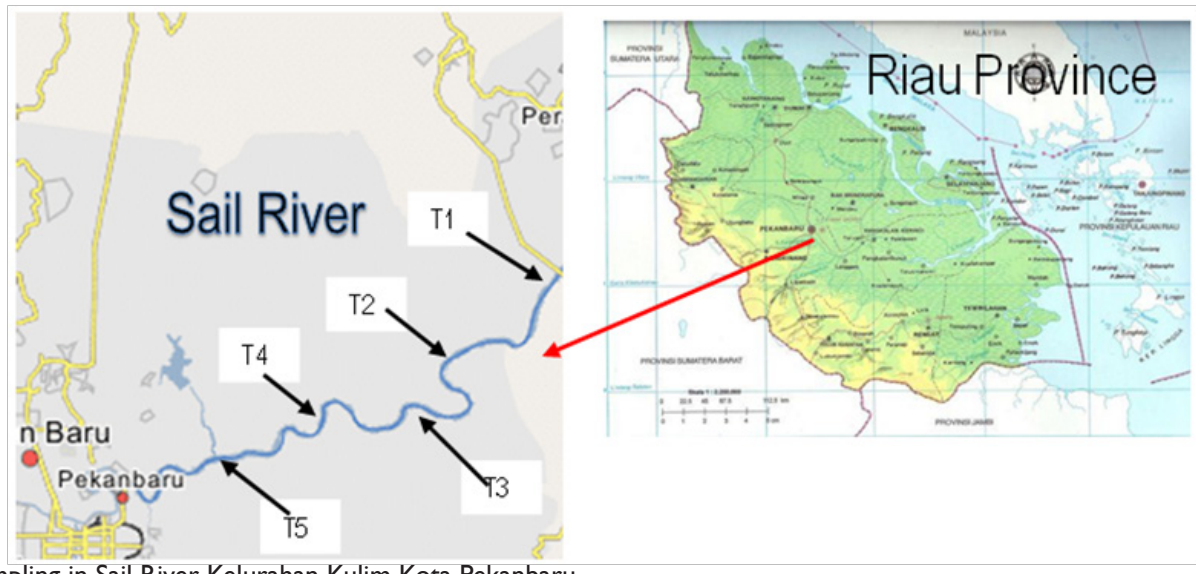

Figure I Location of sampling in Sail River Kelurahan Kulim Kota Pekanbaru. 


\section{Tools and materials}

The material used in this study was river water, aquades, sulfanilate acid solution, naphthyl ethylenediamine dihydrochloride solution, $1 \mathrm{M}$ hydrochloric acid solution, phenol solution, sodium nitro preside solution, manganese sulfate solution, azide alkaliodide solution, concentrated sulfuric acid, solution $0.025 \mathrm{M}$ sodium thiosulfate, $0.03 \mathrm{M}$ potassium permanganate solution, $0.05 \mathrm{M}$ oxalic acid solution, $0.01 \mathrm{M}$ sulfuric acid. The equipment used in this study was the Uv-Vis spectrophotometer, $\mathrm{pH}$ meter, oven, analytic balance, and Gooch cup, paper filter with 0 pore size, $45 \mu \mathrm{m}$, and beaker.

\section{Research methods}

Determination of nitrates: In the $50 \mathrm{~mL}$ pipette, the water sample is inserted into the $100 \mathrm{~mL}$ Erlenmeyer. Then add $1 \mathrm{ml}$ of $1 \mathrm{M} \mathrm{HCl}$ solution, stir it and leave it for \pm 10 minutes, then the absorbance is measured by a spectrophotometer at a wavelength of $275 \mathrm{~nm}$.

Determination of ammonia: In the $25 \mathrm{~mL}$ pipette of the water sample, put into $50 \mathrm{~mL}$ Erlenmeyer, $1 \mathrm{~mL}$ of phenol was added solution, $1 \mathrm{~mL}$ of sodium nitro preside solution and $2 \mathrm{~mL}$ of oxidizing solution. Then the sample is closed and left for 1 hour of measured absorption at a wavelength of $640 \mathrm{~nm}$.

Determination of TDS: The sample was homogenized with a pipette of $50 \mathrm{~mL}$ and filtered with porous filter paper $0,45 \mu \mathrm{m}$. After the samples are filtered, the filter paper is rinsed with water flute. All filters are transferred into a cup that has a fixed weight. The filter in the saucer is evaporated to dryness with a water bath. The cup containing dissolved solids was dried into the oven at $180^{\circ} \mathrm{C}$ for 1 hour, cooled in a desiccator and weighed.

PH determination: In the $150 \mathrm{~mL}$ cup, $100 \mathrm{~mL}$ of sample was inserted then dipped in electrode from the $\mathrm{pH}$ meter, and read the $\mathrm{pH}$ value on the instrument.

Nitrite determination: In the $50 \mathrm{~mL}$ pipette, the sample is put into $100 \mathrm{~mL}$ Erlenmeyer. Then $1 \mathrm{~mL}$ of sulfanilic acid was added, then $1 \mathrm{ml}$ of ethylenediamine dihydrochloride naphthyl acid was added, stirred and left for \pm 10 minutes, then measured the absorbance in the spectrophotometer at a wavelength of $543 \mathrm{~nm}$.

TSS determination: Samples were homogenized, no pipette of $50 \mathrm{ml}$ and filtered through a porous filter paper, $45 \mu \mathrm{m}$ using a cup Gooch. The Gooch Plate contains a filter containing paper and residue which was put into the oven and dried for 1 hour at $103^{\circ} \mathrm{C}-105^{\circ} \mathrm{C}$. The cup was removed from the oven, cooled in a desiccator and weighed.

Determination of DO: In the $50 \mathrm{~mL}$ pipette sample, $1 \mathrm{~mL}$ of $\mathrm{MnSO}_{4}$ and $1 \mathrm{~mL}$ of alkaline iodide azide were added, closed and homogenized, it was allowed to settle for 5 minutes to 10 minutes and added $1 \mathrm{~mL}$ of concentrated $\mathrm{H}_{2} \mathrm{SO}_{4}$, closed, homogenized until the sediment dissolved completely. $\mathrm{S}$ is further titrated with $\mathrm{Na}_{2} \mathrm{~S}_{2} \mathrm{O}_{3} 0$, $025 \mathrm{M}$ with starch indicators until the right blue color is gone.

Determination of BOD: The sample was put into a Winkler bottle, then incubated for 3-5 days in an incubator at a temperature of $20^{\circ} \mathrm{C}$. In the $100 \mathrm{~mL}$ pipette sample was inserted into the Erlenmeyer, added $1 \mathrm{~mL}$ of $\mathrm{MnSO}_{4}$ and $1 \mathrm{~mL}$ of iodide azide alkaline, closed and homogenized, allowed for 5 minutes to 10 minutes and added $1 \mathrm{~mL}$ concentrated $\mathrm{H}_{2} \mathrm{SO}_{4}$, closed, homogenized until the precipitate dissolved completely, then titrated with $0.02 \mathrm{MM} \mathrm{Na}_{2} \mathrm{~S}_{2} \mathrm{O}_{3}$ with starch indicator until the blue color is gone.
COD determination: In the pipette 50mL sample into Erlenmeyer, added $0.5 \mathrm{~mL} 0.01 \mathrm{M}$ sulfuric acid, added $1 \mathrm{~mL} 0.03 \mathrm{M}$ Potassium permanganate, heated to boiling. After leaving it for 2 minutes, a solution of $0.05 \mathrm{~m}$ oxalic acid was added to it. The sample is titrated in hot condition with $0.03 \mathrm{M}$ potassium permanganate solution until the solution is pink.

\section{Results and discussion}

The degree of equality $(\mathrm{pH})$ is an illustration of the amount of activity in hydrogen waters. ${ }^{6}$ In general, the $\mathrm{pH}$ value describes how the level of similarity or basicity of water. Waters with a $\mathrm{pH}$ value $=7$ are neutral, $\mathrm{pH}<7$ is said to be acidic, while $\mathrm{pH}>7$ is said to be alkaline water condition. ${ }^{7}$ At five sampling points, the $\mathrm{pH}$ values range from $6,62-7.19$. The lowest $\mathrm{pH}$ at point 3 , which is the point in the waste disposal pipe. While the highest $\mathrm{pH}$ is at point 2 which is $10 \mathrm{~m}$ before the drain pipe. The $\mathrm{pH}$ value at all points still meets the quality standard, namely $\mathrm{pH}$ 6-9.

Because it oxidizes $\mathrm{Fe} 2+$ in hemoglobin. In this form, the ability to increase oxygen is greatly reduced. ${ }^{8}$ The mechanism of toxicity of oxygen is transported in blood and tissue damage. ${ }^{9}$ Nitrite values ranged from $-0.0013 \mathrm{mg} / \mathrm{L}-0.01140 \mathrm{mg} / \mathrm{L}$. The highest nitrate value is located at point 3 which is the waste disposal pipe which is equal to $0.1140 \mathrm{mg} / \mathrm{L}$. This value does not meet the nitrite quality standard, which is $0.06 \mathrm{mg} / \mathrm{L}$. Increased nitrate points are related to organic matter present in livestock wastewater. Among them is decomposition of organic matter by microorganisms that require large amounts of oxygen (Table 1).

The measurement results of nitrate at five sampling points ranged from $4.0145 \mathrm{mg} / \mathrm{L}-17.9761 \mathrm{mg} / \mathrm{L}$. The biggest value is at T3 which is $17.9761 \mathrm{mg} / \mathrm{L}$, this is the place where the wastewater falls are from the drain pipe. This is not the PP quality standards set out in PP RI. 82 of 2001 of $10 \mathrm{mg} / \mathrm{L}$. This feed flows through the drain pipe. While another point, the measured nitrate value still meets the quality standard.

High nitrate levels can be reduced because it can reduce oxygen dissolved in water can reduce fish populations. The cause of high blood pressure is the decay of dead plants and animals, human waste is becoming increasingly rivers and livestock manure. ${ }^{10} \mathrm{Utami}^{11}$ stated that nitrate is the main form of nitrogen in the waters and is the main nutrient for plant growth and algae. Nitrogen nitrate is very soluble in water and is stable.

Ammonia comes from the oxidation of organic matter microbiologically derived from industrial wastewater, household waste, agriculture, and livestock waste. High ammonia levels indicate pollution in the waters. ${ }^{12}$ The high ammonia value was T3 which was $3.6417 \mathrm{mg} / \mathrm{L}$. The high value of ammonia at the point of reference was organic impurities that came from livestock and leftover animal feed from chicken farm waste. ${ }^{13}$ The direct effect of high ammonia will cause tissue disfigurement to be removed in fish, where it will be disrupted. As a consequence, in chronic conditions, biota normally lives longer lives. ${ }^{14}$

Based on RI Regulation No. 82 of 2001 concerning River Water Quality, the maximum dissolved solids (TDS) is $1000 \mathrm{mg} / \mathrm{L}$. The measurement results for total dissolved solids at five points as a whole are below $1000 \mathrm{mg} / \mathrm{L}$. Thus the results of the TDS tests for river water are still below the required quality threshold standard. The highest value for T3 is T3 which is the point of drainage with a value of $600 \mathrm{mg} / \mathrm{L}$. This is because there is a buildup of dissolved solids 
from the remnants of animal feed and livestock waste in the form. of inorganic materials and organic matter. While the second is the highest point is $340 \mathrm{mg} / \mathrm{L}$ at T4, which is $10 \mathrm{~m}$ after the sewage pipe, this is because it receives a flow of $\mathrm{T} 3$ which still contains a lot of
TDS. The total value of dissolved solids (TDS) in river water is higher than the total suspended solids (TSS). This illustrates the solidity of the river in the form of small solids found in the river is dominated by solids derived from organic wastes.

Table I Results of Water Quality Analysis of the Sail River

\begin{tabular}{lllllllll}
\hline No. & Parameter & Unit & Quality standards & Point I & Point2 & Point 3 & Point 4 & Point 5 \\
\hline I & $\mathrm{pH}$ & - & $6-9$ & 7.12 & 7.19 & 6.62 & 6.75 & 6.85 \\
2 & Nitrite & $\mathrm{mg} / \mathrm{L}$ & 0.06 & -0.0013 & $-0.00 \mathrm{II}$ & $0.1 \mathrm{l} 4$ & 0.0013 & 0,0002 \\
3 & Nitrate & $\mathrm{mg} / \mathrm{L}$ & 10 & 4.0145 & 4.8021 & $17.976 \mathrm{I}$ & 6.3796 & 4.5195 \\
4 & Ammonium & $\mathrm{mg} / \mathrm{L}$ & - & 0.0657 & 0.0529 & 3.6417 & 2.6417 & 0.0785 \\
5 & TDS & $\mathrm{mg} / \mathrm{L}$ & 1000 & 270 & 260 & 600 & 340 & 250 \\
6 & TSS & $\mathrm{mg} / \mathrm{L}$ & 50 & 10 & 10 & 30 & 20 & 10 \\
7 & DO & $\mathrm{mg} / \mathrm{L}$ & 4 & 10.44 & 10.04 & 2.25 & 5.65 & 10.62 \\
8 & BOD & $\mathrm{mg} / \mathrm{L}$ & 3 & 22.4 & 20.42 & 112.2 & 85.2 & 30.6 \\
9 & COD & $\mathrm{mg} / \mathrm{L}$ & 25 & 58 & 60 & 152 & 120 & 64 \\
\hline
\end{tabular}

Source: Primary data (2016), water quality standard refers to PP No. 82 of 200 I

TSS values at all points still meet quality standards. The standard set for TSS based on PP RI No. 82 of 2001 was $50 \mathrm{mg} / \mathrm{L}$. The biggest value is at T3 which is $30 \mathrm{mg} / \mathrm{L}$. This occurs because of the buildup and increase in suspended matter. At T4 the value shown is $20 \mathrm{mg} / \mathrm{L}$, this is the flow of currents that carry and accumulates suspended solids from the T3 to T4 points. According to Weber-Scannell \& Duffy, ${ }^{15}$ suspended solids will reduce the entry into the water. High suspended solids (TSS) will affect turbidity and brightness of river water. ${ }^{16}$ Therefore, the deposition and decay of organic materials can reduce water use value. ${ }^{17}$

The measurement results of dissolved oxygen at five points ranged from $2,25 \mathrm{mg} / \mathrm{L}-10.62 \mathrm{mg} / \mathrm{L}$. The lowest DO value is at T3, which is the sewage pipe with a value of $2.25 \mathrm{mg} / \mathrm{L}$. This quality standard for DO, which is $4 \mathrm{mg} / \mathrm{L}$. The point shows the low freshness of the water due to lack of oxygen in the water. Whereas at other points, the level of freshness is better than T3 and still meets quality standards. This is because oxygen consumption increases.

According to Salmin, ${ }^{18}$ the amount of oxygen in water depends also on the photosynthetic activity of organisms in water. The more bacteria in water will reduce the amount of oxygen in the water. On the surface of the water, the oxygen levels will be higher, because of the process of diffusion between water and free water and the process of photosynthesis. With the increase in depth, there will be a decrease in dissolved oxygen levels because the process of photosynthesis decreases and the oxygen content is widely used and oxidation of organic and inorganic materials. ${ }^{19}$

BOD values ranged from $20,42 \mathrm{mg} / \mathrm{L}-112.2 \mathrm{mg} / \mathrm{L}$ at five sampling points. This is the highest standard, which is $3 \mathrm{mg} / \mathrm{L}$. The highest BOD value is at $\mathrm{T} 3$, which is $112.2 \mathrm{mg} / \mathrm{L}$. The high BOD is the accumulation of organic waste so that the decomposition process increases and causes the dissolved oxygen content to decrease. The value is also shown in T4, which is $85,2 \mathrm{mg} / \mathrm{L}$. This is the closest point to the drain pipe so that it receives water flow from $\mathrm{T} 3$ and the BOD value becomes large (APHA (American Public Health Association), AWWA
(American Water Works Association), \& WEF (Water Environment Federation), 2001).

COD or chemical oxygen demand for oxidizing organic substances in water. The COD number is a measure of water pollution which can naturally be oxidized through the results of reduced oxygen dissolved in water. The highest COD value is at T3, which is $152 \mathrm{mg} / \mathrm{L}$ and T4 which is $120 \mathrm{mg} / \mathrm{L}$. Based on RI Regulation No. 82 In 2001 the maximum value of COD allowed was $25 \mathrm{mg} / \mathrm{L}$. All values at the sampling point were not met the quality requirements. This means that these waters have been polluted by organic materials. Based on the ability of oxidation, the determination of the value of COD is considered to be the best in describing the presence of organic matter, ${ }^{20}$ whether or not biologically decomposed. ${ }^{21-24}$

\section{Conclusion}

From the results of this research that chicken waste has a poor impact on the water quality of the Sail River in Pekanbaru City based on physical and chemical properties in accordance with PP No. 82 of 2001 concerning River Water Quality, especially from the content of nitrite, nitrate, DO, BOD and COD on T3 (point 3), which are sewage pipes that lead directly to the river because of the analysis of these parameters does not meet the standard quality determined by the government. Whereas other points there are those that meet the quality standards and some standards in accordance with PP No. 82 of 2001 concerning River Water Quality.

\section{Acknowledgments}

None.

\section{Funding}

None.

\section{Conflicts of interest}

The authors declared there is no conflict of interest. 


\section{References}

1. Allan JD, Castillo MM. Stream ecology: Structure and function of running waters: 2nd ed. 2007.

2. 5210 biochemical oxygen demand (BOD). Standard Methods for the Examination of Water and Wastewater. 2001.

3. Cummins KW, Sedell JR, Minshall GW, et al. The River Continuum Concept. Canadian Journal of Fisheries and Aquatic Sciences. 2008.

4. Gat JR. Oxygen and hydrogen isotopes in the hydrologic cycle. Annual Review of Earth and Planetary Sciences. 1996;24:225-262.

5. Hamuna B, Tanjung RHR, Suwito S, et al. The concentration of ammonia, nitrate and phosphate in the waters of the depapre district, Jayapura district. EnviroScienteae. 2018;14(1).

6. Handoko YusufM, Wulandari SY. Distribution of nitrates and phosphates in relation to the abundance of phytoplankton in Karimunjawa Islands. Oceanographic Newsletter Marina; 2013.

7. Km S. Water pollution due to high ammonia levels from tempe industry liquid waste. Harahap Faculty of Fisheries and Marine Sciences Universitas Riau Jalan Raya Pekanbaru-Bangkinang. Akuatika Journal. 2013.

8. Kim, BH, Chang IS, Gil GC, et al. Novel BOD (biological oxygen demand) sensor using mediator-less microbial fuel cell. Biotechnology Letters. 2003;25(7):541-545.

9. Lecerf A, Richardson JS. Biodiversity ecosystem function research: Insights gained from streams. River Research and Applications. 2010;26(1).

10. Megawati C, Yusuf M, Maslukah L. Distribution of water quality viewed from nutrients, dissolved oxygen and $\mathrm{pH}$ in the Southern bali strait water. Oceanographic Journal. 2014.

11. Moss B. Water pollution by agriculture. Philosophical Transactions of the Royal Society B: Biological Sciences. 2008.

12. Risamasu FJL, Budi H. Study of phosphate, nitrite, nitrate and silicate substances in the waters of Matasiri Islands, South Kalimantan. Journal of Marine Sciences. 2011.

13. Romadhona B, Yulianto B, Sudarno S. Fluctuations in ammonia content and environmental contamination load of vaname shrimp ponds were intensive with partial harvesting and total harvesting techniques. Saintek Perikanan. 2016;11(2).

14. Salmin. Dissolved oxygen (DO) and biological oxygen needs (BOD) as one indicator to determine water quality. Oseana. 2005.

15. Shuhaimi-Othman M, Lim EC, Mushrifah, I. Water quality changes in Chini Lake, Pahang, West Malaysia. Environmental Monitoring and Assessment. 2007;131(1-3):279-292.

16. Supriyantini E, Soenardjo N, Nurtania, SA. Organic material concentration at mangrove waters in the mangrove information center (PIM), Pekalongan Utara District, Pekalongan City. Buletin Oeanography Marina. 2018;6(1).

17. Takahashi EN, Chaves AG, Akaki F, et al. Self-esteem, propensity for sensation seeking, and risk behaviour among adults with tattoos and piercings. Journal of Public Health Research. 2017;6(3).

18. Tiwary RK. Environmental impact of coal mining on water regime and its management. Water, Water, and Soil Pollution. 2001;132(1-2):185199.

19. Utami TMR, Maslukah L, Yusuf M. Distribution of nitrate (NO3) and phosphate (PO4) in karangsong waters of Indramayu regency. Buletin Oeanography Marina. 2018;5(1).

20. Vannote RL, Minshall GW, Cummins, KW, et al. The river continuum concept. Canadian Journal of Fisheries and Aquatic Sciences. 1980;37(1):130-137.

21. Weber-Scannell PK, Duffy LK. Effects of total dissolved solids on aquatic organisms: A review of literature and recommendation for salmonid species. American Journal of Environmental Sciences. 2007.

22. Yuliana Y, Adiwilaga EM, Harris E, et al. Relationship between phytoplankton abundance and physical-chemical parameters of Jakarta bay water. J Akuatika. 2012.

23. Herfort L, Schouten S, Abbas B, et al. Variations in spatial and temporal distribution of Archaea in the North Sea in relation to environmental variables. FEMS Microbiology Ecology. 2007;62(3):242-257.

24. Sharma RC, Singh N, Chauhan A. The influence of physico-chemical parameters on phytoplankton distribution in a head water stream of Garhwal Himalayas: a case study. Egyptian Journal of Aquatic Research. 2016;42(1):11-21. 